\title{
Invasive species Lemna L. (Lemnaceae) in the flora of Bulgaria
}

\author{
IVAN K. KIRJAKOV ${ }^{1}$ \\ KATYA N. VELICHKOVA ${ }^{2 *}$ \\ ${ }^{1}$ Department of Botany, Paisiy Hilendarski University \\ of Plovdiv, 24 Tsar Assen St., 4000, Plovdiv, Bulgaria \\ ${ }^{2}$ Department of Biology and aquaculture, Agricultural \\ Faculty, Trakia University, Students Campus, \\ 6000 Stara Zagora, Bulgaria

\section{*Correspondence:} \\ e-mail: email:genova@abv.bg
}

Keywords: alien species, invasiveness, Bulgaria, Lemna, morphometrics
Received April 25, 2016.

Revised June 17, 2016.

Accepted June 23, 2016

\section{Abstract:}

Background and Purpose: During the investigations of flora of Bulgaria new species from genus Lemna have been found in Bulgaria.

Materials and methods: They were conducted during the period 2010 - 2015 for which purpose we explored diverse pools in different parts of Bulgaria (hot and cold swamps, spillages of rivers and streams, hot mineral waters). The species were determined by Flora of North America.

Results: In the flora of Bulgaria we found the following new (invasive) species L. minuta KUNTH., L. obscura (AUSTIN) Daubs, L. perpusilla TORR. and L. valdiviana PHILIPI. Their morphology, chorology and ecology was recorded and data about the accompanying species are also given.

Conclusion: Finding these Lemna species in several distant locations in our country is a clear indication that the species is transferred on the territory of Bulgaria a long time ago. The species are most likely invading from neighboring fields in Southeast Europe - Greece, Romania, Turkey and others.

\section{INTRODUCTION}

f the world's known 14 species Lemna (1) for the flora of Bulgaria are reported only three: L. minor L., L. trisulca L. and L. gibba L. $(2,3,4,5,6,7,8)$. All three species are cosmopolitans, but while $L$. minor and L. trisulca are widespread in Bulgaria (characteristic for all floristic regions), L. gibba is known from deposits in the following floristic regions: the Black Sea coast, North-East Bulgaria, Thracian Valley and Tundzha lowland (8). It is included in the Red List of Bulgaria as an endangered species.

In addition to the abovementioned three autochthonous species Lemna in the flora of Bulgaria we found the following new (invasive) species L. minuta Kunth., L. obscura (Austin) Daubs, L. perpusilla Torr. and L. valdiviana Philipr. These species and their morphology, chorology and ecology are the subject of this study.

\section{MATERIALS AND METHODS}

In the middle of February 2010 near the town of Banya - Plovdiv region we found plenty developed duckweed in spills and channels with warm mineral waters. It turned out that this is a new to the flora of Bulgaria species L. minuta. Finding it in unusual time for the growing season for our latitude gave us the occasion to start out a broader and systematic study on the composition and spread of the Lemna genus in Bulgaria. They were conducted during the period 2010 - 2015 for which purpose we explored diverse pools in different parts of Bulgaria (hot and 


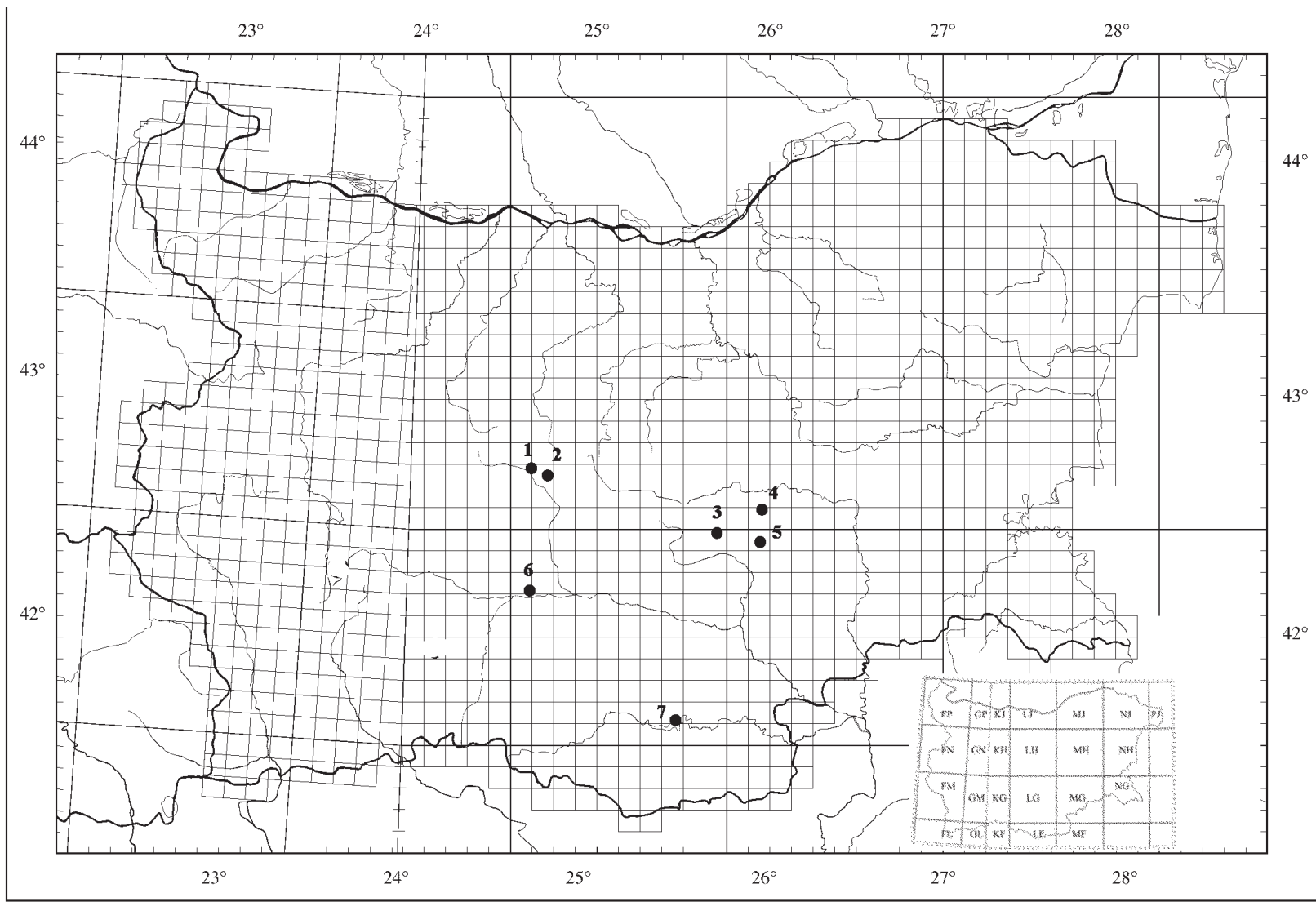

Fig. 1. The main locations of the new invasive species Lemna in Bulgaria (1 - Hissar region, 2 - Banya region, 3 - Stara Zagora region, 4 Karanovo region, 5 - Radnevo region, 6 - Plovdiv region, 7 - Kardzhali region).

cold swamps, spillages of rivers and streams, hot mineral waters) (Fig. 1).

The species were determined by Flora of North America $(9,11)$.

Morphological observations such as the forms and dimensions of the vegetative cells, roots and stipes were conducted under the microscope "Olympus CX31” in the department "Biology and aquaculture” in Trakia University. Herbarium materials from the newly-found species are presented in the herbarium of the Agricultural University - Plovdiv, Bulgaria, № 061397 (L. valdiviana), № 061398 (L.perpusilla), № 061399 (L. obscura), № 061400 (L. minuta) (Fig. 2).

\section{RESULTS AND DISCUSSION}

Lemna minuta Kunth., Nov. Gen. Sp. 1: 372. (1816) Syn.: Lemna minima Phil. Ex Hegelm; Lemna minuscule Herter; Lemna valdiviana Phil. var. abbreviate Hegelm.; Lemna valdiviana Phil. var. minima (Phil.) Hegelm.

Materials of $L$. minuta were collected from different parts of Bulgaria in various pools - cold swamps, spillages of rivers, streams and hot waters.
For the first time we ran across L. minuta on 19.02.2010 in the town of Banya - Plovdiv region $\left(42^{\circ} 32^{\prime} 226^{\prime \prime} \mathrm{N}\right.$ $24^{\circ} 50^{\prime 2} 213^{\prime \prime} \mathrm{E}$ ). It has been developing in a small (about 30 $\mathrm{m}^{2}$ ) warm swamp formed by a hot mineral water flowing out from „Bancheto“ bath. Despite the cold (winter) time the species was developing very well and covered the entire surface of the warm pool.

The individuals from this deposit have the following characteristics: fronds floating, single or 2-5- (7) coherent in groups; $1.4-2.5 \mathrm{~mm}$ long and $0.9-1.5 \mathrm{~mm}$ wide; 1.1 1.6- (2.5) times as long as wide. Roots to $2.0 \mathrm{~cm}$; stipes white, small, tip rounded or slight pointed (Table 1).

Later, on $12^{\text {th }}$ of May 2010 the species was found also in the Eastern Rhodopes. It was developed in a miniature swamp (5-6 $\left.\mathrm{m}^{2}\right)$, on the left from the Kardzhali - Mom-

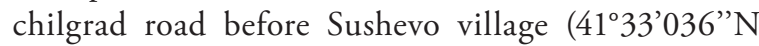
$\left.25^{\circ} 23^{\prime} 381^{\prime \prime} \mathrm{\prime}\right)$. At our subsequent visits in the summer of the same year, the swamp was dried up. The individuals from this field had: fronds floating, single or coherent in groups; $1.8-3.4 \mathrm{~mm}$ long and $1.2-2.2 \mathrm{~mm}$ wide $(1.2$ $-1.4-2.0$ times as long as wide). Roots to $2.5 \mathrm{~cm}$. Stipes white long $0.8-1.2 \mathrm{~mm}$, tip rounded or slight pointed. Flowers: ovaries 1-ovulate, scale with narrow opening at apex. From this deposit the species was collected in flow- 

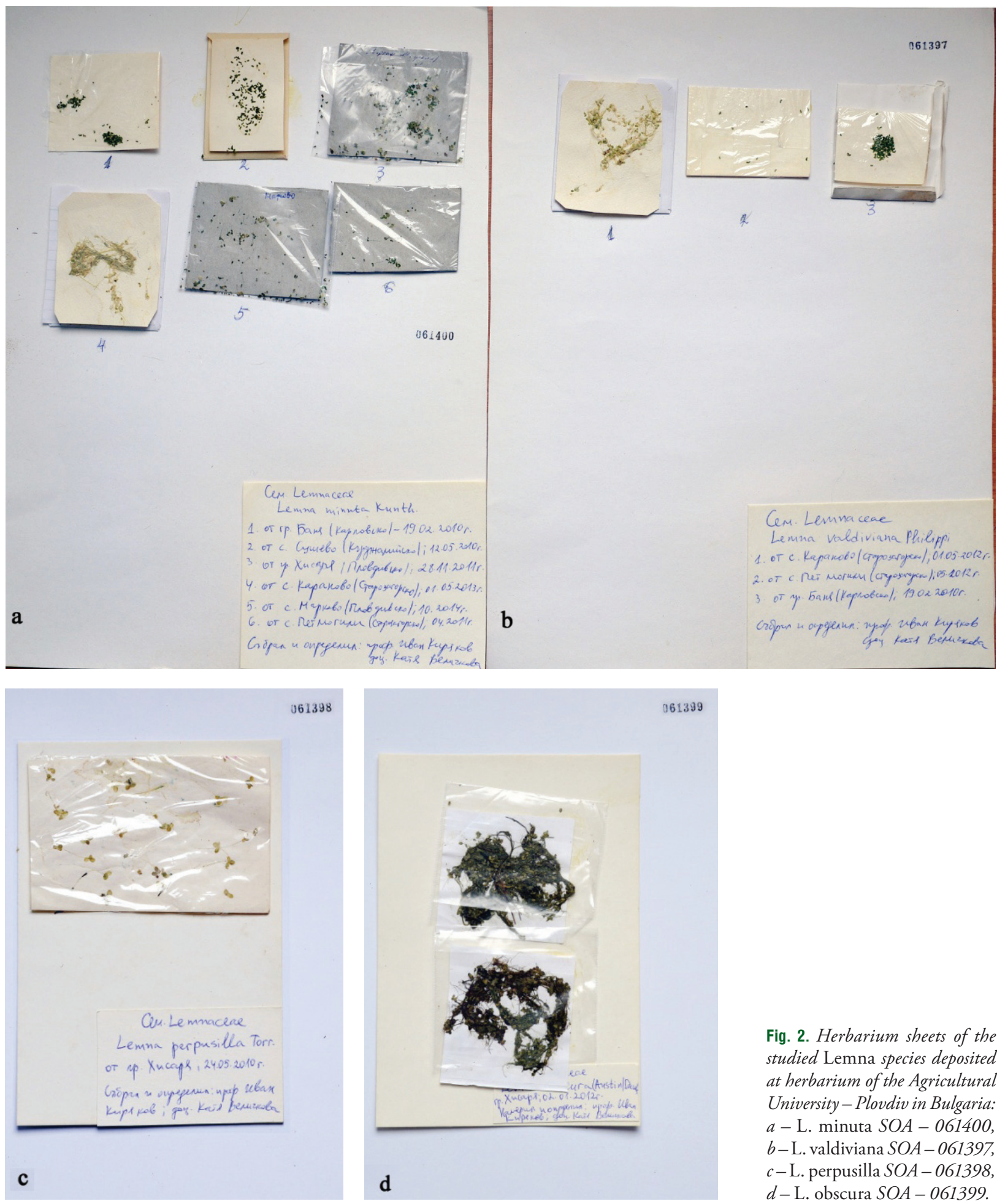

Fig. 2. Herbarium sheets of the studied Lemna species deposited at herbarium of the Agricultural University - Plovdiv in Bulgaria: $a$ - L. minuta $S O A-061400$, $b-\mathrm{L}$. valdiviana $S O A-061397$, $c-\mathrm{L}$. perpusilla $S O A-061398$, $d$ - L. obscura SOA-061399.

ering phase. In the transferred to the laboratory the flowering continued for about 20 days more.

For a third time (on 28.11.2011) the species was found near the of town Hissar in a small, shallow swamp (with an area of about $150 \mathrm{~m}^{2}$ and a depth of $80-120 \mathrm{~cm}$ ) on the north of the Miromir neighbourhood (42 $29^{\prime} 010^{\prime \prime} \mathrm{N}$, $\left.24^{\circ} 43^{\prime} 432^{\prime \prime} \mathrm{E}\right)$, Bulgaria. Develop together with other three species of the family Lemnaceae: Lemna gibba, L. obscura and Wolffi globosa, among highly overgrown with Typha sp. Although the swamp was frozen (covered with crushed, thin icy crust) the population was in good condition. From this field, individuals were green and viability 
Table 1. Measurements of $\mathrm{L}$. minuta from different locations

\begin{tabular}{|c|c|c|c|c|c|}
\hline \multirow{2}{*}{$\begin{array}{l}\text { Locations/month } \\
\text { L. minuta }\end{array}$} & \multicolumn{2}{|c|}{ Fronds } & \multirow{2}{*}{$\begin{array}{l}\text { Ratio fronds } \\
\text { length/width }\end{array}$} & \multirow{2}{*}{$\begin{array}{c}\text { Roots } \\
\text { length }(\mathrm{cm})\end{array}$} & \multirow{2}{*}{$\begin{array}{l}\text { Stipes length } \\
(\mathrm{mm})\end{array}$} \\
\hline & Length(mm) & Width(mm) & & & \\
\hline Banya/February & $1.4-2.5$ & $0.9-1.5$ & $1.1-1.6-(2.6)$ & to 2.0 & $0.6-1.1$ \\
\hline Kardzhali region/May & $1.8-3.4$ & $1.2-2.2$ & $1.2-1.4-(2.0)$ & to 2.5 & $0.8-1.2$ \\
\hline Hissar/November & $0.9-2.5$ & $0.5-1.8$ & $1.1-1.6-(1.8)$ & to 0.5 & $0.8-1.3$ \\
\hline Karanovo/May & $1.3-2.7$ & $1.2-2.3$ & $1.2-1.6-(2.4)$ & to 1.0 & $0.6-2.1$ \\
\hline Banya region/February & $0.8-1.2$ & $0.3-0.6$ & $1.1-1.6-(2.0)$ & to 0.5 & $0.6-1.5$ \\
\hline Plovdiv region/October & $0.7-2.3$ & $0.6-1.2$ & $1.1-1.6-(1.8)$ & to 0.5 & $0.6-1.1$ \\
\hline Radnevo/April & $1.7-3.2$ & $1.0-2.1$ & $1.0-1.4-(2.0)$ & to 2.3 & $0.8-1.2$ \\
\hline
\end{tabular}

(reproduced vegetatively), but smaller: fronds floating, single or $2-5-(7)$ coherent in groups; $0.9-2.5 \mathrm{~mm}$ long and $0.5-1.8 \mathrm{~mm}$ wide (along as wide is $1.1-1.6-1.8$ ). Roots to $0.5 \mathrm{~cm}$, stipes small $(0.8-1.3 \mathrm{~mm}$ long), tip rounded or slight pointed.

$L$ minuta was found on 01.05.2013 at the Thracian tomb at Karanovo - Stara Zagora (42 30' 509“ N, $25^{\circ}$ $\left.54^{\prime} 359^{\prime \prime} \mathrm{E}\right)$. L. valdiviana was also found to inhabit slowflowing and standing water in the marshy meadow under the tomb together with L. minuta. Parameters: fronds intense green, vitality, floating, single or 2 - (3) coherent in groups; with size $1.3-2.7 \mathrm{~mm}$ long and $1.2-2.3 \mathrm{~mm}$ wide. Roots to $1.0 \mathrm{~cm}$ long, stipes $-0.6-2.1 \mathrm{~mm}$ long.

During the winter, on 10.02.2014 L. minuta was found to inhabit another place close to Banya town. Highly developed (like pure culture) in a small (with an area of about $1.5 \mathrm{~m}^{2}$ ), heavily shaded, cement pool with cold, standing water in abandoned greenhouses in „Bancheto “ Bath (4253'973”N, 2483'951”E). The individuals of this field have the following characteristics: fronds intense green, vitality, floating, single or 2 - (3) coherent in groups; with size $0.8-1.2 \mathrm{~mm}$ long and 0.3 $-0.6 \mathrm{~mm}$ wide, roots to $0.5 \mathrm{~cm}$ long, stipes $-0.6-1.5$ $\mathrm{mm}$ long.

At the end of October 2014 by the bed of a fountain located at the foot of the Rhodope Mountains, between Parvnets village and Markovo village - Plovdiv (4207’317”N, 2467’492”E).

At the last habitat the individuals had the following dimensions: fronds floating, single or $2-(3)-4$ coherent in groups; $0.7-2.3 \mathrm{~mm}$ long and $0.6-1.2 \mathrm{~mm}$ wide; a long as wide is $1.1-(1.6)-1.8$. Roots to $0.5 \mathrm{~cm}$; stipes small (0.6-1.1 mm long), tip rounded or slight pointed.

L. minuta were found in the microdam „Pet mogili”, Radnevo - Stara Zagora in April 2011. Roots to $2.3 \mathrm{~cm}$. Stipes white, small (long $0.8-1.2 \mathrm{~mm}$ ), tip rounded orslight pointed ( $42^{\circ} 33^{\prime} 240^{\prime \prime} \mathrm{N}, 2^{\circ} 06^{\prime} 214$ 'E). From the last field the individuals have the following sizes: fronds floating, single or 2-4 coherent in groups; $1.7-3.2 \mathrm{~mm}$ long and $1.0-2.1 \mathrm{~mm}$ wide $(1.0-1.4-2.0$ times as long as wide). In our populations found the fronds are smaller, they do not reach the maximum given in the diagnosis of the Kunth (10) and Landolt (11) dimensions.

In Bulgaria this duckweed grows in slow-moving, calm, and stagnant freshwater habitats.

L. minuta is widespread throughout Europe and it is recorded from France, England, Belgium, Germany, Switzerland, Ukraine, Russia, Netherlands, Portugal, Spain, Sweden, Ireland, Hungary, Slovakia, Romania, Greece, Austria, Italy and Malta $(12,13)$.

Finding L. minuta in several distant locations in our country is a clear indication that the species is transferred on the territory of Bulgaria a long time ago. Its establishment in different types of biotopes in our country shows that the species is quite plastic to the environmental factors - tolerant to temperature, light, accompanying species, salt composition.

Lemna obscura (Austin) Daubs, Ill. Bio. Mon. 34: 20. (1965)

Syn.: Lemna minor Linnaeus var. obscura Austin in A. Gray

This species was found in several distant locations in southern Bulgaria.

It was developed in a small swamp with hot mineral water in the park close to the sanatorium of Banya townPlovdiv area on 01.05.2010. On 06.05.2010 we found it also in a small swamp in which effluent water from the mineral bath „Bancheto" flow out $\left(42^{\circ} 544660^{\prime \prime} \mathrm{N}\right.$, $\left.24^{\circ} 84^{\prime} 123^{\prime \prime E}\right)$.

The materials from this field had the following parameters: fronds floating, solitary or 3-5 coherent in groups; obovate, gibbous; $2.0-3.1 \mathrm{~mm}$ long and $1.2-2.4 \mathrm{~mm}$ wide; $1.1-(1.5)-1.6$ times as long as wide. Roots $8 \mathrm{~cm}$, stipes white, small, tip mostly rounded (Table 2 ).

After a few days, on 12.052010 we found this duckweed in the Eastern Rhodopes - in abandoned fishponds near the Arda river located under the bridge of Vazrojdentsi residential district of the Kardzhali town ( $41^{\circ} 63^{\prime} 742^{\prime \prime} \mathrm{N}$, $\left.25^{\circ} 36^{\prime} 371^{\prime \prime} \mathrm{E}\right)$. 


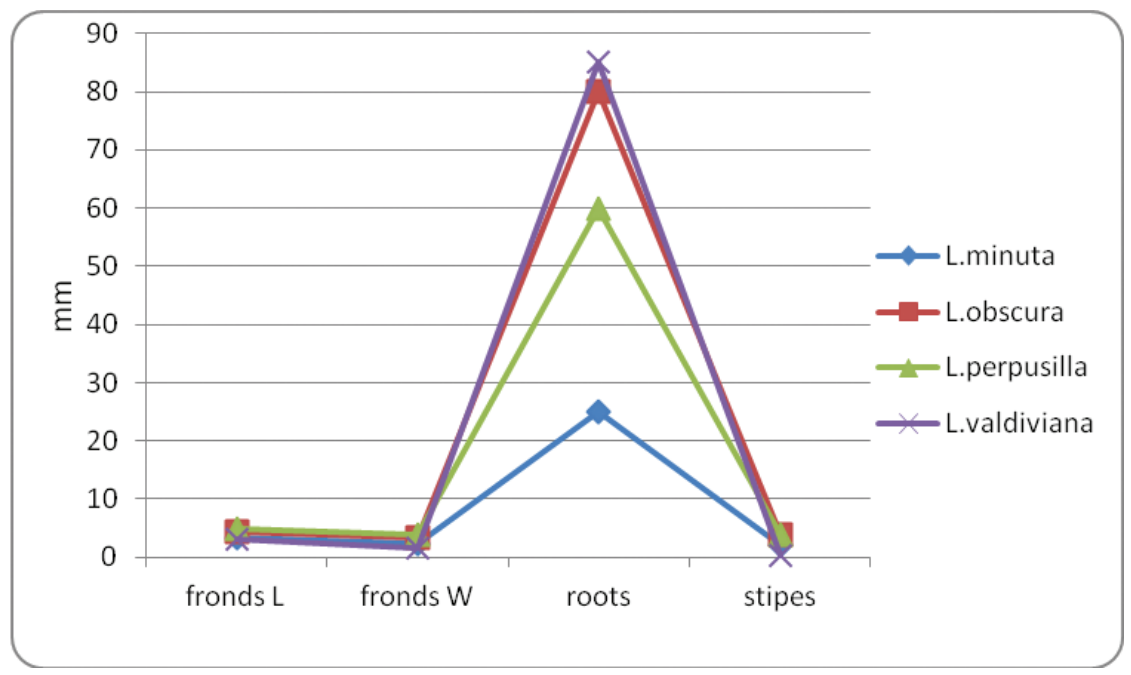

Fig. 3. Morphological features (fronds length, fronds width, roots length, stipes length) in L. minuta, L. obscura, L. perpusilla and L. valdiviana.

The materials from this filed had the following parameters: fronds floating, solitary or $3-(5)$ coherent in groups; obovate, gibbous; $2.5-4.0 \mathrm{~mm}$ long and $2.2-$ $3.2 \mathrm{~mm}$ wide; 1.1 - (1.2) -1.4 times as long as wide. Roots $8 \mathrm{~cm}$, stipes white, small, tip mostly rounded.

In the autumn (on 12.11.2010) we found L. obscura in two relatively distant locations. The first one - in the town Stara Zagora - the lake in front of Zagorka beer factory ( $\left.42^{\circ} 44^{\prime} 535^{\prime \prime} \mathrm{N}, 25^{\circ} 63^{\prime} 715^{\prime \prime} \mathrm{E}\right)$. L. obscura was developed as well in very wellshined periphery of the free water surface as well as in the shadowed area in between of plenty developed Elodea canadensis.

From this place the material had: fronds floating, solitary or $2-3-(5)$ coherent in groups, obovate, gibbous, $1.8-4.5 \mathrm{~mm}$ long and $1.4-3.2 \mathrm{~mm}$ wide; $1.2-(1.6)-$ 1.7 times as long as wide. Veins 3 , midlevel in longer with $4-5-6$ papillae. Roots $1.5-3.5 \mathrm{~cm}$, stipes white, tip mostly rounded, long $1.8-2.0 \mathrm{~mm}$. Some of the individuals of this field are larger (longer by $2 \mathrm{~mm}$ ), and the root is significantly shorter than those in the diagnosis of type $(9,12,14)$.

On the same day (on 12.11.2010) we found L. obscura also in a micro dam near "Pet mogili” to the town of Radnevo - Stara Zagora ( $42^{\circ} 33^{\prime} 240^{\prime \prime}$ N, $26^{\circ} 06^{\prime} 214^{\prime \prime}$ ). The individuals had: fronds floating, solitary or $1-3-$ (or more), coherent in groups; $3.0-4.0 \mathrm{~mm}$ long and $2.0-$ $3.5 \mathrm{~mm}$ wide, $1.2-(1.6)-1.7$ times as long as wide; veins 3 , greatest distance between lateral veins near middle; midline of upper surface with very distinct papillae near apex, and 5-6 some smaller indistinct. Roots to $2.6 \mathrm{~cm}$ long; stipes white, tip mostly rounded.

During the cold months of 2011 - 2012 the species was found in two more locations as well, near the town of Hissar. On 26.11.2011 a small marsh was collected, north of the Miromir neighbourhood $\left(42^{\circ} 29.010^{\prime} \mathrm{N}\right.$, $\left.24^{\circ} 43.432^{\prime} \mathrm{E}\right)$, Bulgaria. It was developed in a community with L. gibba, L. minuta and Wolffi globosa among overgrown with Typha latifolia, Sparganim sp. and others. Although the swamp had been frozen (covered with crushed, thin icy crust) the population was in a good condition.

From this field, the individuals were intensively green, full of live and with the following parameters: fronds floating, single or $2-5$ - (or more) coherent in groups; 1.5 - $4.5 \mathrm{~mm}$ long and $1.0-3.2 \mathrm{~mm}$ wide; 1.1 - (1.4) 1.9 times as long as wide. Roots to $7 \mathrm{~cm}$ long; stipes 1.2 $-1.8 \mathrm{~mm}$ long, tip rounded or slight pointed.

Later, on 02.01.2012 we found it again in slow-moving creek spills over Verigovo neighborhood - of the Hissar town (42 $\left.51^{\circ} 350^{\prime \prime} \mathrm{N}, 24^{\circ} 69^{\prime} 917^{\prime \prime} \mathrm{E}\right)$. Under the thin transparent ice the species population was well represented - full of live, among other higher plants Fontinalis antipyretica L., Callitriche sp., Veronica beccabunga L., Ranunculus aquatilis L., Typha latifolia L., Alisma plantago L. and algae - Tribonema sp., Spirogyra sp. ster. Cladophora sp. From this field the individuals had: fronds floating, solitary or 2-6- (or more), coherent in groups; $2.5-4.5$ $\mathrm{mm}$ long and $1.2-3.5 \mathrm{~mm}$ wide $(1.2-1.4-2.1$ times as long as wide); veins 3 , greatest distance between lateral veins near middle; very distinct papillae near apex, midline of upper surface with some smaller indistinct; roots to $4.5 \mathrm{~cm}$ long; stipes white $2-4 \mathrm{~mm}$ long, tip rounded or pointed.

From this deposit the species was collected also on 25.02.2013. Highly developed in the quiet areas on the river. Fronds floating, solitary or 2 (or more), coherent in groups; 2.6 - (2.9) - $3.6 \mathrm{~mm}$ long and $1.7-(1.9)-2.7$ $\mathrm{mm}$ wide (1.1 - (1.4) - 1.6 times as long as wide); veins 3 , greatest distance between lateral veins near middle; very distinct papillae near apex, midline of upper surface with some smaller indistinct; roots to $4.0 \mathrm{~cm}$ long; stipes white $1.5-3.6 \mathrm{~mm}$ long, tip rounded or pointed. 
Table 2. Measurements of $\mathrm{L}$. obscura from different locations

\begin{tabular}{|c|c|c|c|c|c|}
\hline \multirow{2}{*}{$\begin{array}{l}\text { Locations/month } \\
\text { L. obscura }\end{array}$} & \multicolumn{2}{|c|}{ Fronds } & \multirow{2}{*}{$\begin{array}{l}\text { Ratio fronds } \\
\text { length/width }\end{array}$} & \multirow{2}{*}{$\begin{array}{c}\text { Roots } \\
\text { length }(\mathrm{cm})\end{array}$} & \multirow{2}{*}{$\begin{array}{l}\text { Stipes length } \\
(\mathrm{mm})\end{array}$} \\
\hline & Length $(\mathrm{mm})$ & Width(mm) & & & \\
\hline Banya/May & $2.0-3.1$ & $1.2-2.4$ & $1.1-1.5-(1.6)$ & to 8.0 & $1.2-1.8$ \\
\hline Kardzhali region/May & $2.5-4.0$ & $2.2-3.2$ & $1.1-1.2-(1.4)$ & to 8.0 & $1.6-2.0$ \\
\hline Stara Zagora/November & $1.8-4.5$ & $1.4-3.2$ & $1.2-1.6-(1.7)$ & $1.5-3.5$ & $1.8-2.0$ \\
\hline Radnevo/November & $3.0-4.0$ & $2.0-3.5$ & $1.2-1.6-(1.7)$ & to 2.6 & $1.6-2.0$ \\
\hline Hissar Miromir/November & $1.5-4.5$ & $1.0-3.2$ & $1.1-1.4-(1.9)$ & to 7.0 & $1.2-1.8$ \\
\hline Hissar Verigovo/January & $2.5-4.5$ & $1.2-3.5$ & $1.2-1.4-(2.1)$ & to 4.5 & $2.0-4.0$ \\
\hline
\end{tabular}

Table 3. Measurements of $\mathrm{L}$. perpusilla and $\mathrm{L}$. valdiviana from different locations

\begin{tabular}{|c|c|c|c|c|c|}
\hline \multirow{2}{*}{$\begin{array}{l}\text { Locations/month } \\
\text { L.perpusilla* } \\
\text { L. valdiviana** }\end{array}$} & \multicolumn{2}{|c|}{ Fronds } & \multirow{2}{*}{$\begin{array}{l}\text { Ratio fronds } \\
\text { length/width }\end{array}$} & \multirow{2}{*}{$\begin{array}{l}\text { Roots length } \\
(\mathrm{cm})\end{array}$} & \multirow{2}{*}{$\begin{array}{c}\text { Stipes length } \\
(\mathrm{mm})\end{array}$} \\
\hline & Length(mm) & Width(mm) & & & \\
\hline Banya region/February* & $3.0-4.9$ & $1.7-3.2$ & $1.3-(1.5)-1.7$ & to 6.0 & $2.0-3.5$ \\
\hline Banya/March* & $2.6-5.0$ & $2.0-3.9$ & $1.0-(1.4)-1.7$ & to 6.0 & $2.0-3.5$ \\
\hline Hissar/May* & $2.0-4.9$ & $1.5-3.9$ & $1.2-(1.4)-1.6$ & to 5.0 & $2.0-3.9$ \\
\hline Banya/February** & $1.6-3.0$ & $0.8-1.6$ & $1.6-2.4$ & to 8.5 & 0.3 \\
\hline Radnevo/May** & $1.2-2.6$ & $1.0-1.4$ & $2.0-2.4$ & to 4.0 & 0.3 \\
\hline
\end{tabular}

It is interesting that on its root cap we observed abundance of attached individuals from the green algae Monoraphidium griffithii and on the rest of the root - the diatom Eptemia sp. In the sample besides the above mentioned higher plants are number of other algae are developed as well Oscillatoria princeps, Euglena sp., Tribonema sp., Oedogonium sp.

According to the reviewed literature data, the species is not found in Europe so it is reported to be found and for the first time in Bulgaria.

Lemna perpusilla Torr., Fl. New York 1: 245. (1843)

Syn.: Lemna perpusilla Torr. var. trinervis Austin

The first materials were collected from the area around the town of Banya - Plovdiv on 28.02.2010 - these were found in very well shined water spills and channels flowing out from the hot springs ( $42^{\circ} 53^{\prime} 915^{\prime \prime} \mathrm{N}, 24^{\circ} 83^{\prime} 937^{\prime} \mathrm{E}$ ). Well-developed population occupied an area of several dozen $\mathrm{m}^{2}$.

The individuals of this field are with the following metrics: fronds floating, solitary or $2-3-4-$ (or few), coherent in groups, $3.0-4.9 \mathrm{~mm}$ long and $1.7-3.2 \mathrm{~mm}$ wide $(1.3-1.5-1.7$ times as long as wide), have in a equal size papules above the midline on the upper side - very distinct nodal (above root), and some smaller along midline. Roots are long to $6.0 \mathrm{~cm}$, stipes white, often decaying, usually tip is sharp pointed (Table 3 ).
Later, on 14.03.2010 it was found also in a small completely overshadowed swamp in the woods to the right of way to the station of the Banya town. The small swamp is powered by a local hot spring where the water temperature was $+20^{\circ} \mathrm{C}\left(42^{\circ} 54^{\prime} 132^{\prime \prime} \mathrm{N}, 24^{\circ} 84^{\prime} 583^{\prime} \mathrm{E}\right)$. And in the swamp the population was well developed and covered almost all of its area (around 12-15 $\mathrm{m}^{2}$ ).

From this locus the individuals had the following parameters: fronds floating, ovate-obovate, solitary or $2-5$ -7 , coherent in groups; $2.6-5.0 \mathrm{~mm}$ long and $2.0-3.9$ mm wide (1.0 - $1.4-1.7$ times as long as wide), root to $6.0 \mathrm{~cm}$. Stipes white, usually sharp pointed $-2.0-3.5$ $\mathrm{mm}$ long and $0.2-0.3 \mathrm{~mm}$ wide, often decaying.

On 24.05.2010 we found this duckweed also in the dam to the right of the road from the town of Hissar to the town of Banya ( $\left.42^{\circ} 51^{\prime} 269^{\prime \prime} \mathrm{N}, 24^{\circ} 74^{\prime} 867^{\prime \prime} \mathrm{E}\right)$. It was developed in a highly overshadowed by coastal trees place.

Size data: fronds floating, ovate-obovate, solitary or 2 $-3-5$, coherent in groups; $2.0-4.9 \mathrm{~mm}$ long and $1.5-$ 3.9 mm wide: $1.2-(1.4)-1.6$ times as long as wide; veins 3 , greatest distance between lateral veins near or distal to middle; 1 distinct papilla near apex on upper surface, 2 -3 very distinct papillae above node. Root to $5.0 \mathrm{~cm}$. Stipes white, usually sharp pointed $-2.0-3.9 \mathrm{~mm}$ long and often decaying. In these three localities the individuals are slightly larger and the root is longer than those in the diagnosis of the species (12). 
L. perpusilla is pantropical in distribution, occurring in Africa, Asia and America, and is locally naturalized in some more temperate areas, including France and Italy in southern Europe (15). Now reported and for Bulgaria.

Lemna valdiviana PHILIPPI., Linnaea 33: 239. (1864) Syn. Lemna cyclocosta (Elliott) C. H. Thompson; Lemna torreyi Austin

This species was found in a swamp under the thermal baths of the town of Banya - Plovdiv on 19.02.2010 (4232'226”'N 2450'213'E). Our materials have the following parameters: fronds solitary or $2-5-(7)$ coherent in cluster; lanceolate or ovate, light green, flat, thin; 1.6 $-3.0 \mathrm{~mm}$ long $0.8-1.6 \mathrm{~mm}$ wide; $(1.6-2.4$ times as long as wide). Root is short - to $8.5 \mathrm{~cm}$; stipes white small (only $0.3 \mathrm{~mm}$ long), tip rounded (Table 3).

Fronds are smaller than those given by the diagnosis of type $(11,16)$.

In May 2012, the species was found in a micro dam „Pet mogili” (Radnevo - Stara Zagora) (42³3'240”N, $\left.26^{\circ} 06^{\prime} 214^{\prime \prime} \mathrm{E}\right)$. Fronds solitary 2 -coherent; lanceolate or ovate, light green, flat, thin; $1.2-2.6 \mathrm{~mm}$ long, $1.0-1.4$ $\mathrm{mm}$ wide $(2-2.4$ times as long as wide), root - to $4.0 \mathrm{~cm}$; stipes white small (only $0.3 \mathrm{~mm}$ long), tip rounded.

On 1.05. 2012 we found L. valdiviana in Karanovo village - Slievnsko together with

L. minuta in marshes under the Thracian mound $\left(42^{\circ}\right.$ 30 309“ N, 255 54 ' 359“ E).

Of the three deposits fronds are smaller than those in the diagnosis of type $(11,16 ; 17)$.

L. valdiviana was discovered in Italy and considered as a casual alien species in Agro Pontino, but the rapid colonization of the aquatic environments by Lemna species by means of vegetative reproduction allows us to recognize it as a potential invasive species (19).

L. minuta and L. valdiviana have one vein in frond and similar plant bodies. The vein reaching at least until 3/4 the distance from the node to the top of $L$. valdiviana and not longer than $2 / 3$ of the knots to the top of L. minuta. The analyses of the morphological features of L. minuta and $L$. valdiviana in our study showed clear differences between them. L. minuta is with larger dimensions of the frond, but with short root (to $2.5 \mathrm{~cm}$ ) compared to $L$. valdiviana which has a smaller dimension of the frond, but with a much longer roots (to $8.5 \mathrm{~cm}$ ) (fig. 3). Symmetry of the frond is different between this two species: L. valdiviana-asymmetric, L. minuta-symmetric. The shape of the frond also is different: L. valdiviana lanceolate $(2.0-2.4$ times as long as wide), while on L. minuta is oval (1.1- 1.6 times as long as wide). L. obscura and L. perpusilla have three veins in frond, and in this study L. perpusilla is with larger dimensions of the frond compared to L. obscura. The shapes of fronds in $L$. perpusilla are flat, while in L. obscura are usually hunched.
L. obscura has a very distinctive apical papule. L. obscura has longer roots compared to L. perpusilla.

On the basis of morphological characters in this study about fronds dimensions of $L$. minuta $(0.7-3.4 \mathrm{~mm})$ our results are in agreement with this on the same species found in Europe - Malta: 1.0 - $3.0 \mathrm{~mm}$ (13), in Hungary: (0.5-)1.0-3.0(-4.0) (18), in France: $1.5-3.0 \mathrm{~mm}$ (19), in Italy: $0.8-4.0 \mathrm{~mm}$ (20), in Poland: $1.0-3.0(-$ 4.0) (21), also in America - $0.8-4.0 \mathrm{~mm}$ (11) and Iraq $-1.0-3.0 \mathrm{~mm}(22)$.

The size of fronds of L. obscura and L. perpusilla in our study are slightly larger than those in the diagnosis of the species (11).

L. valdiviana in this study have fronds dimensions 1.2 $-3.0 \mathrm{~mm}$, that are similar to the size of the same species found in Italy (1.2) 1.7-2.6 (4.0) (23).

Finding these new for the country Lemna species shows that the species are most likely invading from neighboring fields in Southeast Europe - Greece, Romania, Turkey and others.

\section{KEY TO DETERMINE THE SPECIES OF THE GENUS}

1. Stems-plates underwater (when blossoms and the fruiter surface), with jagged edges, 2 to 3.5 times longer than wide at the base sharp passing into an arrow handle 2-20 mm

L. trisulca

1. Stems-plates floating above the water surface, with smooth edges, 1-3 times longer than wide

2.

2. Stems-plates with one streak

3. The streak is usually clearly convex, longer than the area of the aerenhim (airway tissue), reaching at least until 3/4 the distance from the node to the top

L. valdiviana

3. The streak is sometimes unclear, very rarely longer than the area of the aerenhim (airway tissue), but not longer than $2 / 3$ of the knots to the top

L. minuta

2. Stems-plates with 3-5 (7) veins

4.

4. The enveloped root at the place of its attachment; its root tip (cap) is usually pointed; long root to $3(-3.5) \mathrm{cm}$; plates are not red colored or with spots of anthocyanin, most often with a very clear papilla from the top side, near the top.

5. Seeds with 35-70 unclear ribs (to count ribs remove membranous pericarp) remaining in the shell of the fruit after bursting (the place of its attachment), root cap wing 2-3 times longer than wide

L. perpusilla 
5. The seeds are with $8-26$ clear ribs falling out after bursting of the fruit; root cap wing 1 to 2.5 times longer than wide

\section{L.aequinoctilaris}

4. The root is not wrapped in (the place of its attachment); the root tip (cap) is usually rounded up; the root is often longer than $3 \mathrm{~cm}$; the plates are often red colored or with spots of anthocyanin, with clear or unclear papilla near the top on their upper side.

6. Plants form a small dyed olive or brown, devoid of roots turioni that sink to the bottom

L. turionfera (in part)

6. The plants usually do not form turions 7 .

7. The width of the airenchym is more than $0,3 \mathrm{~mm}$; if the lower side is colored in red, the color starts from the periphery of the plates

L. gibba

7. The width of the aerenchym is $0,3 \mathrm{~mm}$ or less; the lower side (surface) is colored in red, the staining starts from the point of attachment of the root (edge); the ovary with 1 - ovule

8.

8. The plates on the lower surface are not colored in red (or not so intensely than the upper surface), the greatest distance between the end stripped is near or in the middle of the body

\section{L. minor}

8. The plates are often red from the lower surface (more intensively colored than the top surface); the greatest distance between the end and middle streak is between the top and the middle body

9. Flat plates, in most cases with clear papilla on the central line of the top surface; seeds with 30-60 unclear ribs

\section{L. turionifera (in part)}

9. The plates are usually hunched, with very clear papillae - on the upper surface over the knot sand near the top, but not between the node and the top; 10-16 seeds with clearly pronounced ribs L. obscura

Acknowledgements: Some of materials were brought by Andrey Ivanov Kiriakov, for which we thank him.

\section{REFERENCES}

1. LES D, CRAWFORD D, LANDOLT E, JOHN D, GABEL J, REBECCA K 2002 Phylogeny and systematic of Lemnaceae, the duckweed family. Systematic Botany 27 (2): 221-240

2. STOJANOV N, STEFANOV B 1948 Flora na Balgarija. Nauka i izkustvo, Sofia
3. JORDANOV D 1964 Lemnaceae in Flora Republicae Popularis Bulgaricae, vol. II. Nauka i izkustvo, Sofia, p140

4. STOJANOV N, STEFANOV B, KITANOV B 1967 Flora na Balgarija,Nauka i izkustvo, Sofia, p 563

5. JORDANOV, D, Kochev H 1973 Materials and critical notes on the flora of Bulgaria. Bull. Inst. Bot. Sofia, 24: 241-245

6. ANDREEV N, ANCEV M, KOJUCHAROV S, MARKOVA M, PEEV D, PETROVA A 1992 Determinant of vascular plants. „Nauka and izkustvo", Sofia, p 787

7. DELIPAVLOV D, KOVACHEV I, TERSIISKI D, CHESHMEDJIEV I, GRAMATIKOV D 1992 Qualifier of the plants in Bulgaria. Zemizdad, Sofia, p 499

8. DELIPAVLOV D, CHESHMEDZHIEV I 2003 Key to the Plants in Bulgaria. Agrarian Univ. Acad. Press, Plovdiv, p 591

9. DAUBS E 1965 A mfnograph of Lemnaceae. Illinois Biol. Monogr., 34

10. KUNTH C 1816 Least Duckweed or Minute Duckweed. Nova Genera et Species Plantarum 1: 371-372

11. LANDOLT E 1993 Lemnaceae Gray. Flora of North America 22: $146-150$

12. LANDOLT E 1986 The Family of Lemnaceae - a monographic study. Veröff. Geobot. Inst. ETH, Stiftung Rübel, Zurich 1: 1-566

13. MIFSUD S 2010 First occurences of Lemna minuta Kunth (fam. Lemnaceae) in the Maltese islands. The Central Mediterranean Naturalist 5(2): 1-4

14. BRANQUART E, STIERS I, TRIEST L, VANDERHOEVEN S, VAN LANDUYT W, VAN DAUBS E H 1965 A mofnograph of Lemnaceae. Illinois Biol. Monogr., 34

15. TUTIN T, HEYWOOD V, BURGES N, MOORE D, VALENTINE D, WALTERS S, WEBB D 1980 Flora Europaea. Alismataceae to Orchidaceae (Monocotyledones). Vol. 5, Cambridge University Press, Cambridge, p 452

16. PHILIPPI R 1864 Valdivia Duckweed. Linnaea 33: 239

17. LANDOLT E 1992 Lemnaceae: a duckweed family. J. Arizona Nevada Acad. Sci., 26: 10-14

18. MESTERHÁZY A, KIRÁLY G, VIDÉKI R, LUKÁCS BALÁZS A 2007 Occurrence of Lemna minuta Kunth in Hungary. Flora Pannonica 5: 167-174

19. TOUSSAINT B, BEDOUET F 2005 Les espèces végétales invasives des milieux aquatiques et humides du bassin Artois-Picardie. Agence de l'Eau Artois-Picardie, 38

20. IAMONICO D, ABATI S, IBERITE M 2010 Lemna minuta Kunth (Araceae) nel Lazio (Italia centrale): note morfologiche e osservazioni sui caratteri d'invasivita'. 18 Convegno Forum Natura Mediterraneo "Le specie aliene nel Mediterraneo", 20-21 marzo, Paliano. Available: http://www.naturamediterraneo.com/ primoconvegnoNM/ Accessed June 201120

21. BANASZEK A, MUSIAL K 2009 The new kenophyte in Poland - Lemna minuta Humb., Bonpl. \& Kunth. Acta Societatis Botanicorum Poloniae 78(1): 69-72

22. AL-MAYAH A, AL-SAADI S 2013 Two new generic and three specific records of Lemnaceae to the Aquatic Flora of Iraq. Journal of Plant Studies 2(1): 18:25

23. IBERITE M, IAMONICO D, ABATI S, ABBATE G 2011 Lemna valdiviana Phil. (Araceae) as a potential invasive species in Italy and Europe: Taxonomic study and first observations on its ecology and distribution. Plant Biosystems 145: 751-755 